\title{
Embedded Based Drip Irrigation System using WSN and GSM Module
}

\author{
Mohini Chaudhari ${ }^{1}$, Chaitali Das ${ }^{2}$, Manisha Awari ${ }^{3}$, Pallavi Bhoye ${ }^{4}$,Prof. Satish Shrivastava ${ }^{5}$ \\ ${ }^{1234}$ UG Student, Shivajirao S Jondhale College of Engineering, Dombivli [M.S.], India \\ ${ }^{5}$ Assistant Professor, Shivajirao S Jondhale College of Engineering, Dombivli [M.S.], India
}

\begin{abstract}
Agriculture plays the vital role in economics and survival of people in India. Nowadays Indian agriculture faces a two major problem. We know the government has promoted a free supply of electricity to farmers for irrigation purpose to run their motors and pumps. But it is found that the farmers misusing the electricity to run their home appliances such as radio, TV, fans, and etc. This misuse of electricity has brought a considerable problem for government to supply free electricity. The main objective of this project is to design low cost Automated Irrigation System using a Wireless Sensor Network and GPRS Module. The main aim of this project is to provide embedded based system for irrigation to reduce the manual monitoring of the field and GPRS gives their information. This proposed system recognizes whether the free electricity has been used excluding electric motors for pumping water and if so electricity is being misused, it shuts the total stockpile for the farmers through a tripping circuit. By using wireless networks we can intimate the electricity board about this mal convention. The development of this project at experimental level within rural areas is presented and the implementation has to exhibit that the automatic irrigation can be used.
\end{abstract}

Index Terms: GSM, GPRS, CEPT, LCD

$* * * * *$

\section{INTRODUCTION}

Agriculture is the need of most of the livelihood in indiaand it is one of the main sources of livelihood. It also has a major impact on economy of the country. A major quantity of water is used for irrigation system and therefore $85 \%$ of available fresh water resources are used for yielding agricultural crops. This resource of water will decrease day by day and consumption of water will dominate and increase more than $85 \%$ in upcoming half century. This is due to the high growth in population due to this tremendous growth in population there is huge demand for food. Agriculture is the main source for food production. Using science and technology we need to implement method by which there can be limited consumption of water.

Till date many methods have come into existence where water can be limitedly consumed. A method where monitoring water status and based on status of water whether it is high or low irrigation is scheduled which is based on canopy temperature of plant, which was captured with thermal imaging. Another method is making use of information on volumetric water content of soil, using dielectric moisture sensors to control actuators and save water, instead of the scheduled irrigation at a particular time of day and supplying water only for a specific duration. This above method just opens the valve and supply water to bedding plants when volumetric content of soil will drop below threshold value. In this paper a use of the second method where sensors are placed and based on that water is supplied to the field and intimated to the farmer using software application.
Wireless sensor networks is also called as wireless sensors and actor network, are distributed spatially autonomous sensors to monitor physical or environmental conditions as temperature, pressure sound, moisture etc. And it cooperatively passes these data via network to the main location. WSN is built of few to several thousand nodes, where each node is connected to sensors each sensor network node has typically several parts: a radio transceiver with an internal/external antenna, a microcontroller, an electronic circuit for interfacing with sensors and an energy source such as battery.

\section{LITERATURE REVIEW}

Many research have been done in the agriculture field, most of them are concentrating on sensors parameters and automatic switching mechanisms of pumps based on sensor's signals. The literature review shows that, with the wide spread use of cellular networks, automatic irrigation systems have been applied through wireless technology at the farm area incorporating GSM technology with mobile phone through the mobile network. The technology is one of the factors which limit the implementation of some of the automated irrigation system in developing countries. 


\subsection{GLOBAL SYSTEM FOR MOBILE} COMMUNICATION (GSM)

Table no. 1:History Of GSM

\begin{tabular}{|l|l|}
\hline Year & GSM Development \\
\hline 1982 & $\begin{array}{l}\text { European Conference of Postal and } \\
\text { Telecommunications Administrations } \\
\text { (CEPT) created the Group Special Mobile } \\
\text { (GSM) to develop a standard for mobile } \\
\text { telephone system in Europe. }\end{array}$ \\
\hline 1987 & $\begin{array}{l}\text { Memorandum of understanding was signed } \\
\text { by 13 countries in Europe to develop a } \\
\text { common cell phone system. }\end{array}$ \\
\hline 1989 & $\begin{array}{l}\text { GSM responsibility was transferred to } \\
\text { ETSI }\end{array}$ \\
\hline 1990 & $\begin{array}{l}\text { Phase I of GSM specifications was } \\
\text { published. }\end{array}$ \\
\hline 1991 & $\begin{array}{l}\text { The first GSM network was launched in } \\
\text { Finland }\end{array}$ \\
\hline 1993 & $\begin{array}{l}\text { Over 1 million subscribers were using } \\
\text { GSM phone network. }\end{array}$ \\
\hline
\end{tabular}

GSM is the most popular and widely used digital mobile telephony system in the world. According to GSM world, it is now used by over 1.5 billion people all over the world. Hence the Ubiquity of GSM enables international roaming arrangements between mobile phone operators and provides their subscribers the use of the phone in many parts of the World. Besides that, gsm is considered a second generation (2g) cell phone system as both the signalling and speech channels are digital which differs from the previous technology.

GSM also found a low-cost implementation of the SMS, short message service, which has since been supported on other cellular phone standards as well. For example, the worldwide emergency telephone number feature (112) is included. Gsm uses narrowband time division multiple access (TDMA) for voice and short messaging service (SMS). TDMA is a technology used in digital mobile phone communication that divides each cellular channel into 3 time slots to increase the amount of data that can be carried. GSM digitizes and compresses data, then sends it down a channel with 2 other user data in its own time slot.

\section{ANALYSIS AND DESIGN}

\subsection{BLOCK DIAGRAM}

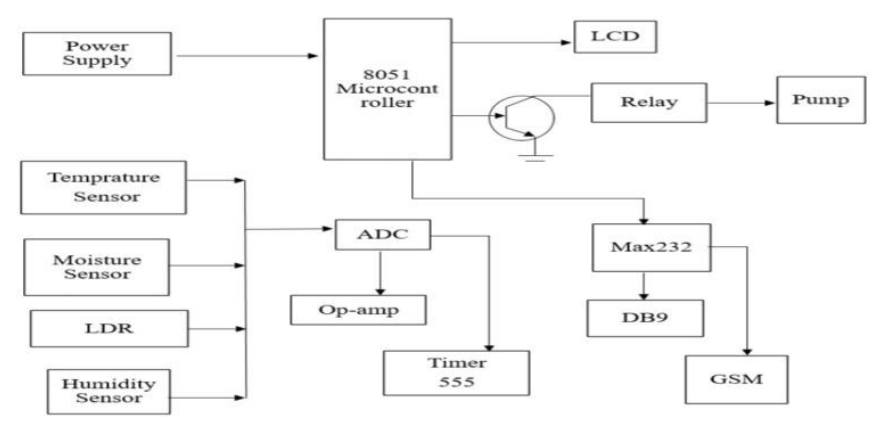

Figure no. 1: Block Diagram of System

\subsection{CIRCUIT DIAGRAM}

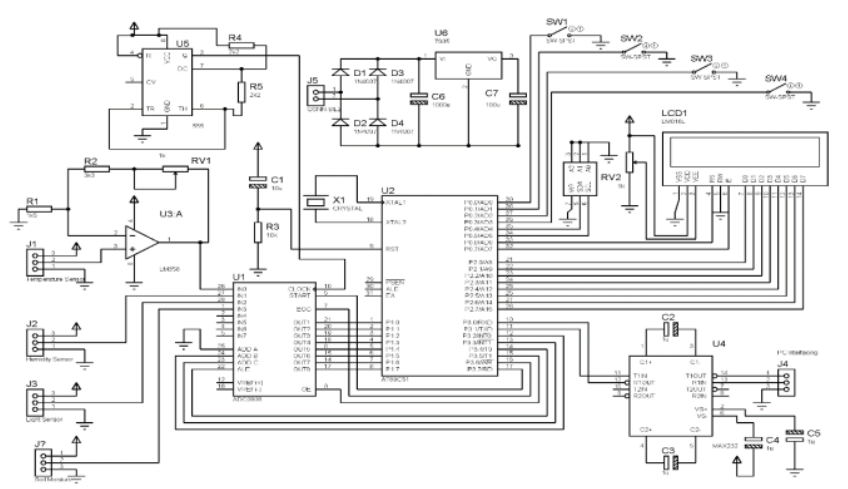

Figure no. 2: Circuit Diagram of System

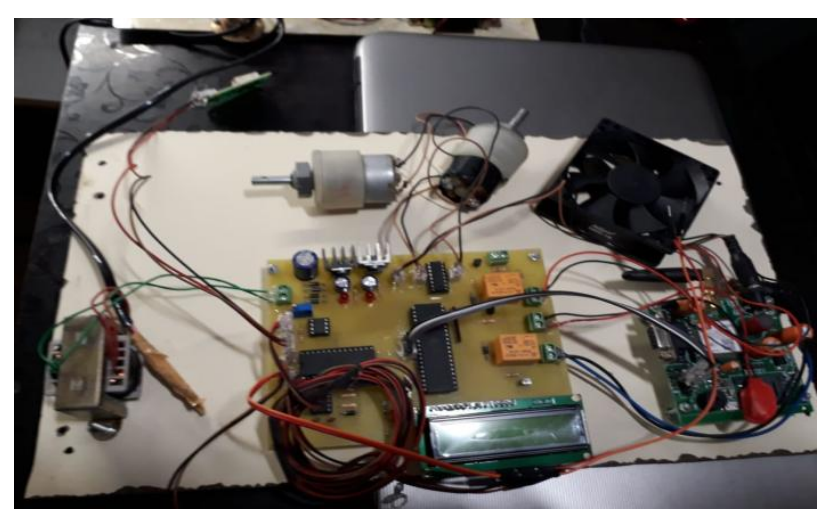

Figure no. 3: Designed System

\subsection{WORKING}

The working of the system is as follows:

Microcontroller is interfaced with soil moisture sensor, humidity sensor, GSM, LCD, Temperature sensor and water pump. First initialize GSM and wait until it obtains the network. The green light indicates GSM is ON and red light indicates the network strength. Once it obtains complete network there will be delay in blinking of red light. Then initialize LCD, it will display all the statements given and the status of field.

Using the inputs from soil moisture sensor, we turn $\mathrm{ON}$ the water pump manually as well as automatically. When the soil is moisturized and soil moisture sensor senses moisture 
presence it keeps the pump off and when it senses absence of moisture it switches on the pump and supply water to field. Then we need to continuously monitors the sensors and based on that we take some actions. It supplies water until it again sense the presence of moisture, once it senses moisture is present, it switches of the pump.Temperature sensor gives room temperature. This whole process is automatic process of irrigation system using wireless sensor networks and GSM module.

\section{RESULTS}

With the implementation of system explained in this paper our, the moisture content of the three different types of field were measured successfully. Motor automatically turned on or off with the different level of moisture level content in the soil. The system meets the moisture content of the crops with their specific level of moisture content

\section{APPLICATIONS}

The system explained in this paper can be used for following applications: -

- To calculate and store the temperature and humidity of a boiler in the industry.

- To store flow of the water flowing from the dam or a canal

- To monitor / display the level of the liquid inside the container

- Also this system communicates with a PC and sends various data like level of humidity, liquid flow, and temperature of water.

\section{CONCLUSION}

With the knowledge of new techniques in 'Electronics', we are able to make our life more comfortable. One such application of electronics is used in "Embedded Based Drip Irrigation System Using WSN and GSM Module" The approach we followed and which is explained in this paper is novel and has achieved the objectivessatisfying user needs and requirements. The system is very economical in terms of hardware component and power consumption. The system helps in saving of water and electricity. The automated irrigation system explained in this paper is feasible and cost effective. Hence we can conclude that the required goals and objectives of our project have been achieved.

\section{FUTURE SCOPE}

The scope of our system explained in this paper is immense. The future implications of the paper are very great considering the amount of time, money and resources it saves. The paper can be used as a reference or as a base for realizing a scheme to be implemented in other systems of greater level such as GSM pump controller, weather updates using mobile phones, pest control, control farming vehicles using mobiles, etc. The system itself can be modified to achieve a complete Automatic Irrigation system which will then create a platform for the user to interface between him and the agricultural field.

\section{REFERENCES}

[1] Veena Divyak, AyushAkhouri,A Real time implementation of a GSM based Automated Irrigation Control System using drip Irrigation Methology (Volume 4, Issue 5, May 2013)

[2] Syed Mubarak, Shoukhi Khan, Sahana.N, Megha B, S.Sujatha, "Automated Irrigation System Using Wireless Sensor Networks And GSM Module", International Journal of Advance Research In Science And Engineering IJARSE], Vol. No.4, Special Issue (01), May 2015.

[3] m. guerbaoui, y. el afou, a. ed-dahhak, a. lachhabpc-based automated drip irrigation system (Vol. 5 No.01 January 2013)

[4] Purnima, S.R.N Reddy, "Design of Remote Monitoring and Control System with Automatic Irrigation System using GSM Bluetooth", on IJCA,2012

[5] Cottef F. (2001): LabVIEW: programmationet applications. Dunod, pp. 415.

[6] Eddahhak, A.; Lachhab, A.; Ezzine, L.; Bouchikhi, B. (2007): Performance evaluation of a developing greenhouse climate control with a computer system. AMSE Journal Modelling C, 68 (1), pp. 53-64.

[7] Elattir H. (2005): La conduiteet le pilotage de l'irrigation goutte-àgoutteenmaraîchage. Bulletin mensueld' informationet de liaison duprogramme national de transfert de technologieen agriculture (PNTTA), pp. 124

[8] Gonzalez, R .A.; Struve, D.K.; Brown L.C. (1992): A computer controlled raingun irrigation system for container plant production Hort Technology, 2(3), pp. 402-407.

[9] Howell, T.A. (2001): Enhancing water use efficiency in irrigated agriculture. Agron. J, 93, pp. 281-289.

[10] Abou Kheira A. A. (2009). Comparison among different irrigation systems for deficit- irrigated transgenic and non transgenic yellow corn in the Nile Valleyll. Agricultural Engineering International: the CIGR Ejournal. Manuscript LW 08 010. Vol. XI:1 25.

[11] Mansour, H.A, You sifEl-Melhem impact the automatic control of closed circuits raingun irrigation system on yellow corn growth and yield(International Journal of Advanced Research (2013), Volume 1, Issue 10, 33-42)

[12] P. Varady, Z. Benyo, and B. Benyo, "An open architecture patient monitoring system using standard technologies", IEEE Trans. Inf. Technol. Biomed., vol. 6, no. 1, pp. 95-98, Mar. 2002. 